\title{
Pridelek, morfološki razvoj in hranilna vrednost zelinja lucerne med rastno sezono v osrednji Sloveniji: analiza časovnih potekov
}

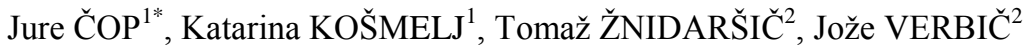

Received December 22, 2017; accepted Februar 21, 2018.

Delo je prispelo 22. decembra 2017, sprejeto 21. februarja 2018.

\section{IZVLEČEK}

Čas košnje je zelo pomemben dejavnik količine in kakovosti pridelka krme enovrstnih koševin. Zato smo želeli analizirati časovne poteke pridelka zelinja, morfološkega razvoja in parametrov kakovosti lucerne med rastno sezono ter jih povezati s časom košnje. Poljski poskus v split-plot zasnovi z dvema blokoma smo izvedli v Ljubljani leta 2016. Glavne parcele so predstavljale 4 rastne cikluse (C1-C4), podparcele pa 9 tedenskih terminov za merjenje pridelka in vzorčenje zelinja. Rast lucerne je bila $\mathrm{v}$ prvi polovici rastne sezone boljša kot $\mathrm{v}$ drugi. Pridelek zelinja je $\mathrm{v}$ zadnjih dveh ciklusih hitro dosegel maksimum in se nato zmanjševal. Statistična analiza je pokazala, da so linearni regresijski modeli primerni za opisovanje časovnih potekov naslednjih spremenljivk: morfološkega razvoja (PRF), surovih beljakovin (SB), vlaken, netopnih v nevtralnem detergentu (NDV) in neto energije za laktacijo (NEL). Morfološki razvoj lucerne je bil hitrejši poleti kot pomladi ali jeseni, vendar je po tej lastnosti med ciklusi izrazito odstopal samo prvi. Kakovost lucerne je bila predvsem zaradi počasnejšega razvoja $\mathrm{v}$ celoti najboljša $\mathrm{v} \mathrm{C} 1$, kar se je bolj odrazilo pri NDV in NEL kot pri SB. C1 je bil po kakovosti lucerne enakovreden samo $\mathrm{C} 4$ na začetku rasti. Upoštevajoč pridelek in vsebnost NEL je bila optimalna starost lucerne ob košnji od 28 do 35 dni spomladi in poleti ter od 35 do 42 dni jeseni.

Ključne besede: lucerna; pridelek; morfološki razvoj; hranilna vrednost; časovni potek

\author{
ABSTRACT \\ HERBAGE YIELD, MORPHOLOGICAL \\ DEVELOPMENT AND NUTRITIVE VALUE OF \\ LUCERNE DURING GROWTH SEASON IN CENTRAL \\ SLOVENIA: ANALYSIS OF TIME PATTERNS
}

Cutting time is a pivotal factor affecting herbage yield and nutritive value of forage crop monocultures. Therefore, our objectives in this lucerne study were to analyse temporal patterns of herbage yield, morphological development and quality parameters over growth season, and to relate these patterns to the time of cutting. A field experiment in split-plot design with two block replications was conducted in Ljubljana in 2016. Four growth cycles (C1-C4) were assigned to the main plots, and nine weekly intervals at which herbage yield was measured and herbage samples taken were assigned to the sub-plots. Dry-matter herbage yield accumulated faster during the first half of the season than during the second one. It peaked early in each of the last two growth cycles and after that started to decrease. Statistical analysis showed that linear regression models are acceptable to describe time patterns of morphological development stages (MSW) and contents of crude protein $(\mathrm{CP})$, neutral detergent fibre (NDF) and net energy for lactation (NEL). MSW increased faster during the summer than during the spring or autumn, but only $\mathrm{C} 1$ was distinct in this pattern. Lucerne forage quality was generally the highest in $\mathrm{C} 1$ mainly due to slower morphological development. This high quality reflected more in NDF and NEL than in CP. In respect of the quality, only $\mathrm{C} 4$ at the beginning of the growth was equivalent to $\mathrm{C} 1$. Considering yield and content of NEL optimal age of lucerne at cutting was from 28 to 35 days in spring and summer and from 35 to 42 days in autumn.

Key words: lucerne; herbage yield; morphological development; nutritive value; time pattern

\footnotetext{
1 Univerza v Ljubljani, Biotehniška fakulteta, Oddelek za agronomijo, Jamnikarjeva 101, SI-1111 Ljubljana, Slovenija, ${ }^{*}$ Corresponding author: jure.cop@bf.uni-lj.si

2 Kmetijski inštitut Slovenije, Hacquetova ulica 17, Ljubljana
} 


\section{UVOD}

Lucerna (Medicago sativa L.) je $\mathrm{v}$ svetovnem merilu najpomembnejša gojena krmna metuljnica. Njena ocenjena pridelava obsega 32 mio ha (Russelle, 2001). Kot krmna rastlina je cenjena zaradi velikega rastnega potenciala, kakovostne krme in obstojnosti sestojev. Letni pridelek krme je običajno večji od $10 \mathrm{t}$ sušine ha ${ }^{-1}$, v zelo ugodnih razmerah za rast, ob namakanju in dolgi rastni sezoni lahko ta znaša od $20 \mathrm{t}$ do $25 \mathrm{t}$ sušine ha ${ }^{-1}$ (Lloveras in sod., 2012). Lucerna je predvsem beljakovinsko bogata voluminozna krma $\mathrm{z}$ vsebnostjo surovih beljakovin (SB) okoli $200 \mathrm{~g} \mathrm{~kg}^{-1}$ sušine. Pri zelo mladi krmi lahko vsebnost SB preseže $300 \mathrm{~g} \mathrm{~kg}^{-1}$ sušine (McGraw in Marten, 1986). Odlikuje se tudi po hitri prebavljivosti $\mathrm{v}$ vampu in $\mathrm{s}$ tem povezanim potencialom za povečano zauživanje krme (Marten in sod., 1988). Kot druge gojene metuljnice tudi lucerna na splošno vsebuje trikrat več kalcija in dvakrat več železa kot gojene trave (Whitehead, 1972). Lucerna ima tudi pridelovalne in prehranske pomanjkljivosti. Slabo prenaša prekomerno vlažnost tal, pomanjkanje glavnih mineralnih hranil in kisla tla $(<\mathrm{pH} 6)$. V primerjavi s črno deteljo se njena hranilna vrednost $\mathrm{v}$ smislu prebavljivosti in vsebnosti vlaknine znatno hitreje slabša $\mathrm{s}$ časom rasti in zorenjem, kar je posledica povečane lignifikacije stebel (Kühbauch in Pletl, 1981; Kühbauch in Voigtländer, 1981; Albrecht, 1983). Siliranje lucerne je v primerjavi s travami zahtevnejšs zaradi njene večje puferske kapacitete in manjše vsebnosti vodotopnih ogljikovih hidratov (Rizk, 2004; Verbič in Verbič, 2017).

Morfološki razvoj lucerne, ki poteka skupaj z rastjo, je zelo kompleksen zaradi tvorbe stebelnih stranskih poganjkov, številnih socvetij in $\mathrm{s}$ tem povezanega dolgega obdobja cvetenja ter odganjanja naknadnih poganjkov iz prizemnih brstov med staranjem sestojev (po 7 tednu rasti). Pravimo tudi, da ima lucerna poudarjen nedeterminanten način rasti. Iz tega izhaja, da je morfološka sestava sestoja lucerne - razen na začetku rasti - zelo raznolika, in da ni mogoče vizualno zadovoljivo opredeliti njegove razvojne faze. Zato sta Kalu in Fick (1981) za potrebe posrednega ocenjevanja kakovosti krme razvila postopek, s katerim določimo tehtano povprečno morfološko razvojno fazo sestoja (PRF). Pri tem postopku poganjke $\mathrm{v}$ vzorcu lucerne najprej razvrstimo $\mathrm{v}$ razvojne faze od 0 do 9 . Maso suhih poganjkov posameznih faz nato uporabimo za izračun tehtanega povprečja, kjer je potrebno upoštevati tudi številčno kodo razvojne faze. Postopek je možno poenostaviti tako, da izpustimo sušenje in stehtamo sveže poganjke, kar ne vpliva na rezultat analize (Božičković in sod., 2013).

Ker se kakovost krme med rastjo lucerne razmeroma hitro slabša, je za njeno uspešno vključevanje v krmne obroke zelo pomembna izbira ustreznega termina košnje. Ta izbira je vedno kompromis med količino in kakovostjo pridelka. Na splošno se pridelek krme pri lucerni linearno povečuje med zgodnjo rastjo do cvetenja. Kasneje se povečevanje pridelka krme upočasni in se med zorenjem lucerne celo zmanjša. Slednje je predvsem posledica odpadanja listov $\mathrm{s}$ starejših poganjkov, ki ga stresne razmere (npr. glivične okužbe, zasenčenje, suša) lahko še pospešijo. Dosegljive informacije o spreminjanju pridelka lucerne med rastjo so skope in omejene glede števila zajetih rastnih ciklusov (Kühbauch in Pletl,1981; McGraw in Marten, 1986; Bowley in sod., 1988; Brink in sod., 2010; Kruz in sod., 2016). Nasprotno od količine se kakovost lucerne med rastjo zmanjšuje, vendar na splošno manj med prvim ciklusom kot med naslednjimi. Objavljene raziskave se večinoma nanašajo na spreminjanje vsebnosti SB, vlaken, netopnih $\mathrm{v}$ nevtralnem (NDV) in kislem detergentu (KDV) in prebavljivost suhe snovi (npr. Kalu in Fick, 1983; McGraw in Marten, 1986; Hall in sod., 2000; Brink in sod. 2010). Za časovni potek vsebnosti neto energije za laktacijo (NEL) smo v literaturi našli le podatke za prvo košnjo (Žnidaršič in sod., 2015). V tej raziskavi so časovni poteki preučevanih parametrov kakovosti opisani z linearnimi ali kvadratnimi funkcijami.

Namen raziskave je bil ugotoviti časovne poteke povečevanja pridelka suhega zelinja, morfološkega razvoja sestoja in spreminjanja kakovosti krme med rastjo lucerne po ciklusih ter jih med seboj primerjati $\mathrm{z}$ uporabo statističnih modelov. Namen raziskave je bil tudi ugotoviti zgornjo mejo za pridelek SB in NEL pri njunih sprejemljivih vsebnostih za krmljene živali. Poskus je potekal na območju $s$ predalpskim podnebjem, za katerega navedena problematika še ni bila preučevana.

\section{MATERIALI IN METODE}

\subsection{Postavitev in opis poskusa}

Raziskavo smo opravili na osnovi poljskega poskusa, ki smo ga postavili 10. aprila 2015 na poskusnem polju Biotehniške fakultete v Ljubljani $\left(46^{\circ} 03^{\prime} \mathrm{S}, 14^{\circ} 28^{\prime} \mathrm{V}\right.$,
$300 \mathrm{~m} \mathrm{n}$. m.). Poskus je bil v split-plot zasnovi z dvema ponovitvama. Na glavne parcele so bili razporejeni štirje rastni ciklusi (C1-C4), ki so zajeli celo rastno sezono. Rastni ciklus pomeni 70 dnevno rast lucerne od 
temperaturnega praga spomladi (C1), oziroma od predhodne košnje, opravljene ob začetku cvetenja lucerne $(\mathrm{C} 2-\mathrm{C} 3)$. Na podparcele je bilo razporejenih devet tedenskih terminov za meritve pridelka in vzorčenja lucerne. Velikost osnovne parcele je bila 1,32 $\mathrm{m} \times 5,0 \mathrm{~m}$. Izbrana je bila srbska sorta lucerne 'NS Mediana ZMS V', ki je nastala s križanjem lucerne in srpaste meteljke. Setev smo opravili s parcelno sejalnico Wintersteiger na medvrstno razdaljo $11 \mathrm{~cm}$ pri setvenem odmerku $25 \mathrm{~kg} \mathrm{ha}^{-1}$. Seme je bilo tik pred setvijo inokulirano $\mathrm{z}$ bakterijo Rhizobium meliloti (Dangeard, 1926) De Lajudie et al., 1994, pripravek NSNitragin. Ob setvi smo posevek pognojili z mineralnim gnojilom $400 \mathrm{~kg} \mathrm{ha}^{-1}$ (NPK 7:20:30), naslednje leto, 23. marca 2016 pa z $900 \mathrm{~kg} \mathrm{ha}^{-1}$ (PK 10:30). Rastni ciklusi v letu 2016, rezultate katerega predstavlja ta prispevek, so se po vrsti od prvega do četrtega začeli: 25. marca, 6 . maja, 17. junija in 29. julija. Začetek $\mathrm{C} 1$ je bil določen $\mathrm{s}$ temperaturnim pragom $\left(5{ }^{\circ} \mathrm{C}\right)$, ostali pa $\mathrm{z}$ datumi predhodnih košenj.

\subsection{Tla in vremenske razmere}

$\mathrm{Na}$ poskusnem polju se nahajajo rjava aluvialna tla na karbonatnem pesku in produ. $\mathrm{V}$ zgornji $30 \mathrm{~cm}$ plasti je meljasta ilovica, pod njo je do globine $110 \mathrm{~cm}$ zmerno oglejena meljasto glinasta ilovica. Na začetku poskusa so bila tla v zgornji $22 \mathrm{~cm}$ plasti nevtralna $(\mathrm{pH} 6,9 \mathrm{v}$ $\left.\mathrm{CaCl}_{2}\right)$, srednje do dobro preskrbljena s fosforjem (140 $\mathrm{g} \mathrm{P}_{2} \mathrm{O}_{5} \mathrm{~kg}^{-1}$ tal, $\mathrm{AL}$ metoda) in srednje preskrbljena $\mathrm{s}$ kalijem (168 $\mathrm{g} \mathrm{K}_{2} \mathrm{O} \mathrm{kg}^{-1}$ tal, AL metoda). Vsebnost organske snovi je bila srednja (3,8\% v suhih tleh). Na poskusnem polju je postavljena cevna drenaža, po kateri odteka padavinska voda, ki pronica skozi tla.

Povprečna temperatura zraka je bila v letu 2016 nižja za $0,2{ }^{\circ} \mathrm{C}$ od povprečnih $10,9^{\circ} \mathrm{C}$ za obdobje 1981-2010 na meteorološki postaji Ljubljana-Bežigrad. Najbolj so odstopali naslednji meseci: februar s $3{ }^{\circ} \mathrm{C}$ višjo temperaturo od referenčnega povprečja $\left(1,9^{\circ} \mathrm{C}\right)$, maj $\mathrm{s}$ $1,8^{\circ} \mathrm{C}$, avgust $\mathrm{s} 1,2^{\circ} \mathrm{C}$, oktober s $1,7^{\circ} \mathrm{C}$ in december s $2,5{ }^{\circ} \mathrm{C}$ nižjimi temperaturami od referenčnih povprečij $\left(15,8{ }^{\circ} \mathrm{C}, 20,6{ }^{\circ} \mathrm{C}, 11,2{ }^{\circ} \mathrm{C}, 1,2{ }^{\circ} \mathrm{C}\right)$. Konec aprila se je ohladilo in padlo je $15 \mathrm{~cm}$ snega. Padavin je bilo v letu 2016 za $82 \mathrm{~mm}$ manj od povprečja za referenčno obdobje $(1361 \mathrm{~mm})$. Njihova razporeditev med rastno sezono je bila ugodna za uspevanje rastlin razen $\mathrm{v}$ avgustu in septembru, ko je bila suša. Vremenske razmere za rast lucerne so bile na splošno dobre, razen $\mathrm{v}$ zadnji dekadi aprila in v sredini maja, ko so minimalne temperature zraka padle pod $5{ }^{\circ} \mathrm{C}, 30$. aprila celo na $-1,2$ ${ }^{\circ} \mathrm{C}$. Od sredine septembra so bile ugodne razmere za razvoj lucernine rje (Uromyces striatus Schröter), ki je oslabila rast lucerne.

\subsection{Meritev pridelka in morfološka analiza}

Za ugotavljanje pridelka zelinja smo pokosili notranji del parcele v velikosti $1,2 \mathrm{~m} \times 5,0 \mathrm{~m}$. Rez kosilnice je bila nastavljena na višino $7 \mathrm{~cm}$. Z vsake parcele smo od pokošene lucerne odvzeli približno kilogram vzorca, kateremu smo določili vsebnost sušine ter vsebnosti SB, NDV in NEL. Pridelek suhega zelinja smo izračunali iz pridelka svežega zelinja in vsebnosti sušine. Pridelek SB in NEL smo izračunali $\mathrm{z}$ množenjem pridelka suhega zelinja in deležem SB oziroma NEL v sušini.

Analizo povprečne morfološke razvojne faze (PRF) smo opravili po postopku, ki sta ga razvila Kalu in Fick (1981) Z upoštevanjem poenostavitve pri tehtanju razvojnih frakcij poganjkov (Božičković in sod., 2013). Posamezni vzorci lucerne, namenjeni za to analizo, so bili odvzeti s kvadratne površine $0,1 \mathrm{~m}^{2}$ na višini 3,5 $\mathrm{cm}$. Poganjke smo postrigli z ročnimi škarjami. PRF smo izračunali po enačbi:

$P R F=\sum_{i=0}^{9}\left(i \cdot m_{i}\right) / \sum_{i=0}^{9} m_{\mathrm{i}}$,

kjer pomeni $P R F$ povprečno razvojno fazo sestoja na podlagi tehtanja svežih poganjkov, $i$ zaporedno številčno kodo razvojne faze posameznega poganjka (09), $m_{i}$ maso poganjkov $\mathrm{v}$ fazi $i$. Meritve pridelka in analize PRF smo delali tedensko na dveh ponovitvah za vseh devet terminov znotraj posameznega ciklusa. Vsi štirje ciklusi so bili obdelani na enak način. Prva meritev in analiza sta se začeli 14 dni po začetku rasti pri $\mathrm{C} 1, \mathrm{C} 3$ in $\mathrm{C} 4$ ter 21 dni po začetku rasti pri $\mathrm{C} 2$.

\subsection{Analiza hranil in neto energije}

Vsebnosti SB in NDV smo določili po NIRS metodi (bližnja infrardeča refleksijska spektrometrija; Roberts in sod., 2004). Vsebnosti NEL smo izračunali $\mathrm{Z}$ enačbami, ki jih je za lucerno in detelje predlagal GfE (2016). Pri tem smo uporabili podatke o sestavi krme [SB, surova vlaknina (SVl), surove maščobe (SM), pepel, KDV] in volumnu plina, ki nastane pri inkubaciji vzorcev z vampovim sokom. Vse navedene parametre, potrebne za izračun NEL, smo določili po NIRS metodi. Kalibracijske enačbe za NIRS metodo so bile razvite na podlagi 485 vzorcev trav in metuljnic, med njimi 88 vzorcev lucerne (od tega 11 iz našega poskusa), ki smo jim vsebnosti SB določili po Kjeldahlovi metodi (International organisation for standardisation, 2005), vsebnosti SVl po International organisation for standardisation (2000), vsebnosti SM brez predhodne hidrolize po Uredbi komisije (ES) 152/2009, vsebnosti pepela po International organisation for standardisation (2002), vsebnosti KDV in NDV po Van Soestu in sod. (1991), količino plina, ki nastane pri inkubaciji vzorcev $\mathrm{z}$ vampovim sokom pa s pomočjo Hohenheimskega 
plinskega testa (Menke in sod., 1979), oziroma $\mathrm{z}$ modificirano različico, ki sta jo opisala Blümmel in Ørskov (1993). Med vzorci za NIRS umeritve je bilo tudi 11 vzorcev iz tega poskusa. NIRS meritve so potekale na zračno suhih in skozi $1 \mathrm{~mm}$ sito zmletih vzorcih zelinja.

\subsection{Statistična analiza podatkov}

Za vsak preučevani parameter (pridelek, PRF, SB, NDV in NEL) posebej smo po ciklusih grafično prikazali njegovo odvisnost od časa rasti. Za to smo uporabili metodo lokalne regresije. Slike gladilnikov so pokazale, da je linearni regresijski model sprejemljiv za PRF, SB, NDV in NEL. V linearnem regresijskem modelu smo upoštevali tri napovedne spremenljivke: dan $\mathrm{v}$ ciklusu (začeli smo $\mathrm{z}$ vrednostjo 0 , ki se nanaša na prvo meritev, opravljeno na 14. oziroma 21. dan), ciklus ter njuno interakcijo. S takim modelom dobimo ocene parametrov s standardno napako za vsak ciklus posebej ter koeficient determinacije za celoten model. Vrednost za presečišče $a$ predstavlja napoved ob začetku meritev, vrednost za naklon premice $b$ pa trend. Na osnovi navedenega linearnega regresijskega modela smo paroma primerjali presečišča in naklone po ciklusih. Za odvisnost pridelka zelinja od časa rasti nismo izdelali napovednih modelov. Opise časovnega spreminjanja pridelka smo naredili na podlagi gladilnikov.

Analiza je bila izvedena s programskim in grafičnim okoljem R s paketi lattice, nlme ter multcomp (R Core Team, 2016).

\section{REZULTATI}

\section{1 Časovni potek pridelka zelinja}

Pridelek suhega zelinja lucerne se je linearno povečeval $\mathrm{v}$ vseh ciklusih do 42. dneva rasti (Slika 1). Po tem dnevu se je priraščanje malo zmanjšalo $\mathrm{v}$ prvih dveh ciklusih in občutno v zadnjih dveh. Odstopa $\mathrm{C} 2$, kjer je bila rast $\mathrm{v}$ začetku zelo počasna zaradi nizkih temperatur zraka. Tako smo prvo meritev pridelka lahko opravili en teden kasneje kot $\mathrm{v}$ drugih treh ciklusih. Povprečni pridelek 21. dne $\mathrm{v}$ tem ciklusu $\left(1,1 \mathrm{t}\right.$ sušine $\left.\mathrm{ha}^{-1}\right)$ je bil podoben povprečnima pridelkoma $\mathrm{v}$ predhodnem in naslednjem ciklusu na 14 . dan. Temu počasnemu začetku rasti je sledila najhitrejša rast. Zato je bil v $\mathrm{C} 2$ dosežen tudi maksimalni pridelek $\left(6,4 \mathrm{t}\right.$ sušine ha $^{-1}$ na 70. dan). V C3 in $\mathrm{C} 4$ se je pridelek začel zmanjševati od 63. oziroma 42. dne naprej.

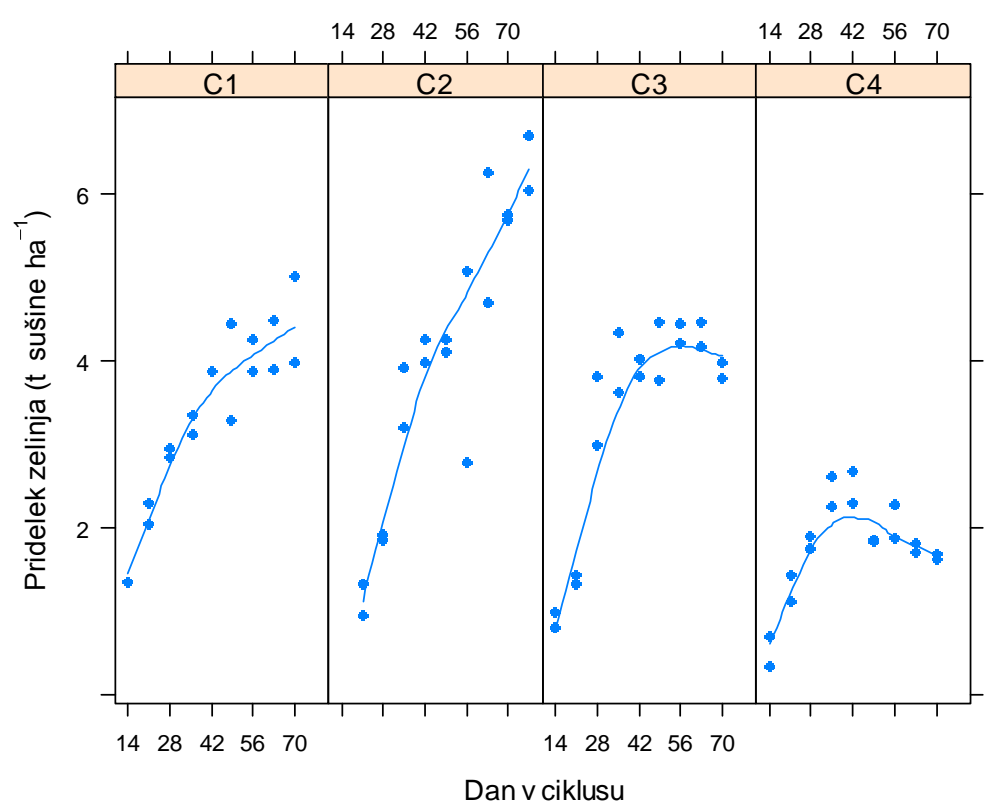

Slika 1: Časovni potek pridelka zelinja lucerne po ciklusih (C1-C4) med rastno sezono $2016 \mathrm{v}$ predalpskem podnebju Slovenije. Krivulje so gladilniki, dobljeni z lokalno regresijo.

Figure 1: Time pattern of herbage dry matter yield accumulation during four growth cycles (C1-C4) in the preAlpine climate of Slovenia in the season 2016. Smooth curves were obtained by local regression. 


\subsection{Modelirani časovni poteki PRF ter vsebnosti SB, NDV in NEL}

$\mathrm{Na}$ osnovi grafičnih prikazov časovnih potekov PRF ter vsebnosti SB, NDV in NEL po ciklusih smo ugotovili, da je linearna zveza sprejemljiva (Slika 2). Vse premice se dobro prilegajo gladilnikom. Pojasnjena variabilnost $\left(R^{2}\right)$ v regresijskem modelu za posamezne parametre je velika in znaša od $88,7 \%$ za $\mathrm{SB}$ do $93,9 \%$ za PRF (Preglednica 1).

Analiza časovnega poteka PRF je pokazala, da med presečišči premic po ciklusih ni statistično značilnih razlik, so pa statistično značilne razlike med nakloni. Največji naklon imata premici pri $\mathrm{C} 2$ in $\mathrm{C} 3$, med katerima ni statistično značilne razlike $(p>0,05)$. Srednji naklon ima premica pri $\mathrm{C} 4$, najmanjšega pa premica pri $\mathrm{C} 1$. Razlike $\mathrm{v}$ naklonih premic med ciklusi so razen navedene izjeme statistično značilne $(p<0,01)$.
Najmanjši naklon pri $\mathrm{C} 1$ je 2,6 krat manjši kot pri najbližjem C4 (Preglednica 1).

Analiza časovnega poteka SB je pokazala, da ima največjo vrednost presečišče premice pri $\mathrm{C} 4$. Razlike med njim in drugimi tremi presečišči so statistično značilne $(p<0,05)$. Največja razlika $\mathrm{v}$ presečiščni vsebnosti SB (58,7 $\mathrm{g} \mathrm{kg}^{-1}$ sušine) je bila ugotovljena med $\mathrm{C} 3$ in $\mathrm{C} 4$. Po naklonu so premice razdeljene $\mathrm{v}$ dve skupini in sicer $\mathrm{V}$ skupino $\mathrm{z}$ manjšim absolutnim naklonom $(\mathrm{C} 1, \mathrm{C} 3)$ in $\mathrm{v}$ skupino $\mathrm{z}$ večjim absolutnim naklonom (C2, C4). Med skupinama so $\mathrm{v}$ naklonu premic statistično značilne razlike $(p<0,001)$, razen med $\mathrm{C} 2$ in $\mathrm{C} 3$, kjer je razlika mejno statistično značilna $(p=0,06)$. Primerjava dveh najbolj različnih naklonov pokaže, da se je vsebnost SB pri C1 dvakrat počasneje zmanjševala kot pri C4.

Preglednica 1: Ocene koeficientov $(a, b)$ in njihove standardne napake za linearne regresije časovnih potekov PRF ter vsebnosti SB, NDV in NEL v zelinju lucerne po ciklusih (C1-C4). Koeficienti determinacije $\left(\mathrm{R}^{2}\right)$ so podani za vse štiri cikluse skupaj. Presečišča znotraj posameznega parametra kakovosti, označena $\mathrm{z}$ isto črko, niso statistično značilno različna $(p>0,05)$. Enako velja za naklone.

Table 1: Estimated linear regression coefficients $(a, b)$ and their standard errors for predicting time patterns of MSW, and contents of CP, NDF and NEL in herbage dry matter of lucerne analysed separately for cycles (C1-C4). Coefficients of determination $\left(\mathrm{R}^{2}\right)$ are given for all four cycles together. Intercepts denoted with the same letter are not significantly different within particular parameter of quality $(\mathrm{p}>0.05)$. The same holds for slopes.

\begin{tabular}{llllll}
\hline $\begin{array}{l}\text { Parameter } \\
\text { kakovosti }\end{array}$ & Ciklus & Presečišče $a$ & St. napaka $(a)$ & Naklon $b$ & St. napaka $(b)$ \\
\hline & C1 & $0,96 \mathrm{a}$ & 0,269 & $0,036 \mathrm{c}$ & 0,008 \\
PRF & $\mathrm{C} 2$ & $0,44 \mathrm{a}$ & 0,268 & $0,128 \mathrm{a}$ & 0,008 \\
$\left(R^{2}=93,9 \%\right)$ & $\mathrm{C} 3$ & $0,81 \mathrm{a}$ & 0,268 & $0,140 \mathrm{a}$ & 0,008 \\
& $\mathrm{C} 4$ & $0,73 \mathrm{a}$ & 0,268 & $0,093 \mathrm{~b}$ & 0,008 \\
\hline & $\mathrm{C} 1$ & $244 \mathrm{bc}$ & 7,114 & $-1,43 \mathrm{a}$ & 0,204 \\
$\mathrm{SB}$ & $\mathrm{C} 2$ & $250 \mathrm{~b}$ & 6,792 & $-2,40 \mathrm{bc}$ & 0,204 \\
$\left(R^{2}=88,7 \%\right)$ & $\mathrm{C} 3$ & $222 \mathrm{c}$ & 6,792 & $-1,64 \mathrm{ab}$ & 0,204 \\
& $\mathrm{C} 4$ & $281 \mathrm{a}$ & 6,792 & $-2,96 \mathrm{c}$ & 0,204 \\
\hline & $\mathrm{C} 1$ & $279 \mathrm{bc}$ & 14,35 & $3,12 \mathrm{~b}$ & 0,398 \\
$\mathrm{NDV}$ & $\mathrm{C} 2$ & $328 \mathrm{ab}$ & 14,29 & $4,87 \mathrm{a}$ & 0,397 \\
$\left(R^{2}=90,4 \%\right)$ & $\mathrm{C} 3$ & $366 \mathrm{a}$ & 14,29 & $3,72 \mathrm{ab}$ & 0,397 \\
& $\mathrm{C} 4$ & $268 \mathrm{c}$ & 14,29 & $4,77 \mathrm{a}$ & 0,397 \\
& $\mathrm{C} 1$ & $6,65 \mathrm{a}$ & 0,145 & $-0,028 \mathrm{a}$ & 0,004 \\
$\mathrm{NEL}$ & $\mathrm{C} 2$ & $5,93 \mathrm{~b}$ & 0,145 & $-0,039 \mathrm{ab}$ & 0,004 \\
$\left(R^{2}=89,5 \%\right)$ & $\mathrm{C} 3$ & $5,70 \mathrm{~b}$ & 0,145 & $-0,031 \mathrm{ab}$ & 0,004 \\
& $\mathrm{C} 4$ & $6,53 \mathrm{a}$ & 0,145 & $-0,043 \mathrm{~b}$ & 0,004 \\
\hline
\end{tabular}

Opomba: Vrednosti za presečišča pri $\mathrm{C} 1, \mathrm{C} 3$ in $\mathrm{C} 4$ se nanašajo na 14. dan rasti, pri $\mathrm{C} 2$ pa na 21. dan rasti.

Note: $a=$ intercept, $b=$ slope, $\mathrm{MSW}=\mathrm{PRF}, \mathrm{CP}=\mathrm{SB}, \mathrm{NDF}=\mathrm{NDV}$

Regresijske premice časovnih potekov NDV so glede presečišč razdeljene na skupino $\mathrm{z}$ manjšima vrednostma $(\mathrm{C} 1, \mathrm{C} 4)$ in na skupino $\mathrm{z}$ večjima vrednostma $(\mathrm{C} 2, \mathrm{C} 3)$. Med skupinama so $\mathrm{v}$ vrednosti presečišč po parih statistično značilne razlike $(p<0,05)$, razen med $\mathrm{C} 1$ in $\mathrm{C} 2$, kjer je razlika mejno statistična značilna $(p=0,07)$.
Največja razlika v presečiščni vsebnosti NDV $\left(97 \mathrm{~g} \mathrm{~kg}^{-1}\right.$ sušine) je bila ugotovljena med $\mathrm{C} 3$ in $\mathrm{C} 4$. V naklonih premic se ciklusi manj razlikujejo kot po presečiščih. Statistično značilni razliki v naklonu premic sta med C1 in $\mathrm{C} 2$ oziroma $\mathrm{C} 4(p<0,05)$. 
Jure ČOP et al.

Odnosi med regresijskimi premicami časovnih potekov NEL so podobni kot pri NDV. Presečišča delijo premice na skupino $\mathrm{z}$ večjima vrednostma $(\mathrm{C} 1, \mathrm{C} 4)$ in na skupino $\mathrm{z}$ manjšima vrednostma $(\mathrm{C} 2, \mathrm{C} 3)$. Med skupinama so $\mathrm{v}$ vrednostih presečišč po parih močno statistično značilne razlike $(p<0,001)$. Povprečna razlika v vsebnosti NEL med skupinama znaša $0,8 \mathrm{MJ}$ $\mathrm{kg}^{-1}$ sušine. $\mathrm{V}$ naklonih premic je bila ugotovljena edina statistično značilna razlika med $\mathrm{C} 1$ in $\mathrm{C} 4(p<0,05)$. Pri $\mathrm{C} 4$ se je vsebnost NEL s časom rasti 1,5 krat hitreje zmanjševala kot pri $\mathrm{C} 1$.
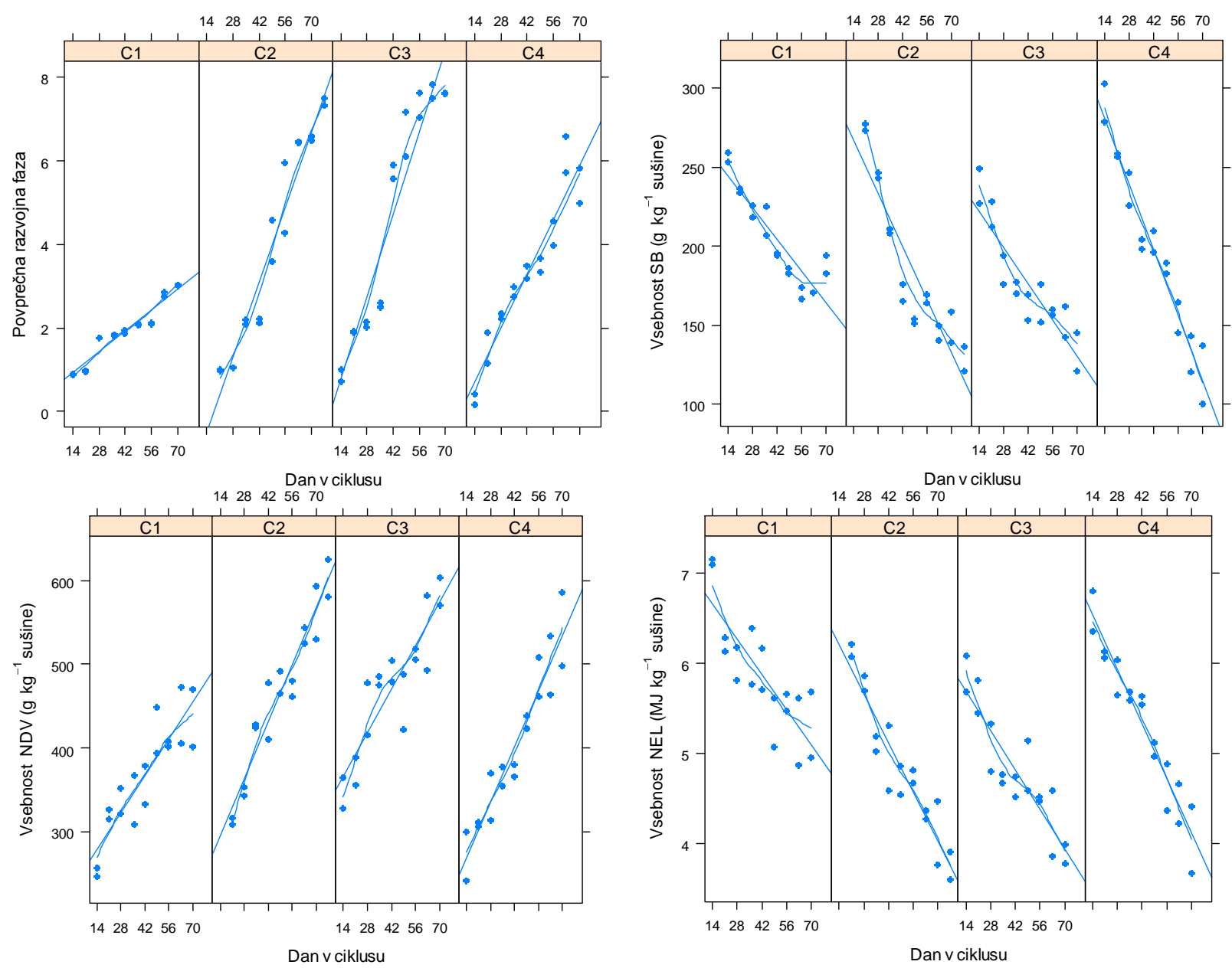

Slika 2: Časovni potek PRF ter vsebnosti SB, NDV in NEL v zelinju lucerne po ciklusih (C1-C4) med rastno sezono 2016 v predalpskem podnebju Slovenije. Na slikah so regresijske premice in gladilniki.

Figure 2: Time pattern of MSW and contents of CP, NDF and NEL in herbage dry matter of lucerne during four growth cycles (C1-C4) in the pre-Alpine climate of Slovenia in the season 2016. Both linear regression curves and smooth curves are presented.

\subsection{Primerjava časovnih potekov pridelkov in vsebnosti SB in NEL}

Sliki 3 in 4 prikazujeta časovne poteke povprečnega pridelka in vsebnosti SB oziroma NEL v zelinju lucerne po posameznih ciklusih, narejenih na podlagi meritev. Namen slik je predvsem prikazati odnose med poteki navedenih parametrov. Pridelka SB in NEL sta na splošno potekala podobno med sezonsko rastjo lucerne - v prvih dveh ciklusih sta oba naraščala do konca, v zadnjih dveh pa se od sredine naprej nista povečevala oziroma sta padala. Vsebnosti SB in NEL so se s časom rasti pri vseh ciklusih zmanjševale $\mathrm{v}$ mejah od $291 \mathrm{~g}$ do $119 \mathrm{~g} \mathrm{SB} \mathrm{kg}^{-1}$ sušine in od 7,1 MJ do 3,8 MJ NEL kg-1 sušine. Pri $\mathrm{C} 1$ je vsebnost $\mathrm{SB}$ tudi pri zelo poznih vzorčenjih presegala $150 \mathrm{~g} \mathrm{~kg}^{-1}$ sušine, pri ostalih ciklusih pa se je zmanjšala na približno $120 \mathrm{~g} \mathrm{~kg}^{-1}$ sušine. Vsebnosti NEL so se pri $\mathrm{C} 1$ proti koncu vzorčenja približale vrednosti $5 \mathrm{MJ} \mathrm{kg}^{-1}$ sušine, pri $\mathrm{C} 2$, $\mathrm{C} 3$ in $\mathrm{C} 4$ pa so se zmanjšale pod $4 \mathrm{MJ} \mathrm{kg}^{-1}$ sušine. 


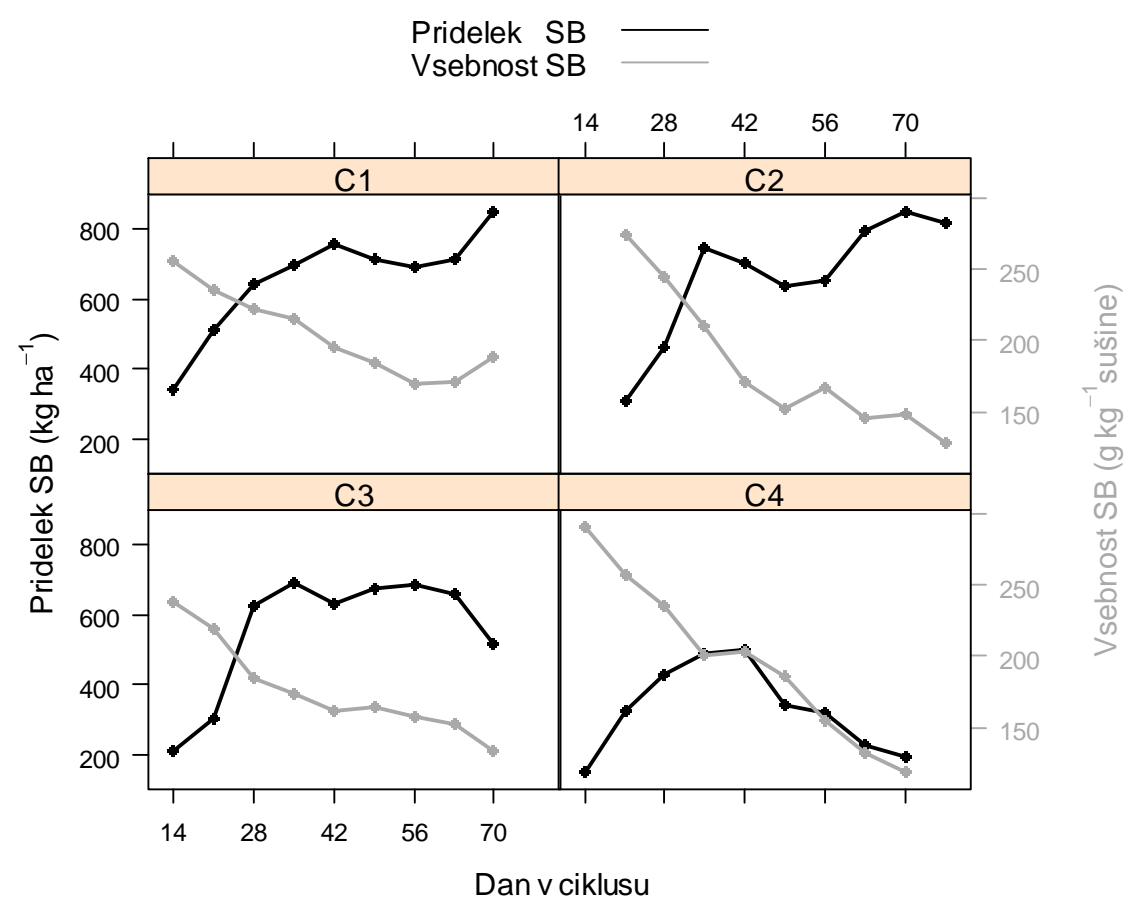

Slika 3: Časovni potek pridelka in vsebnosti SB v zelinju lucerne po ciklusih (C1-C4) v rastni sezoni 2016 v predalpskem podnebju Slovenije. Posamezne točke so povprečja dveh meritev.

Figure 3: Time pattern of yield and content of $\mathrm{CP}$ in lucerne herbage during four growth cycles $(\mathrm{C} 1-\mathrm{C} 4)$ in the preAlpine climate of Slovenia in the season 2016. Data points are averages of two independent measurements.

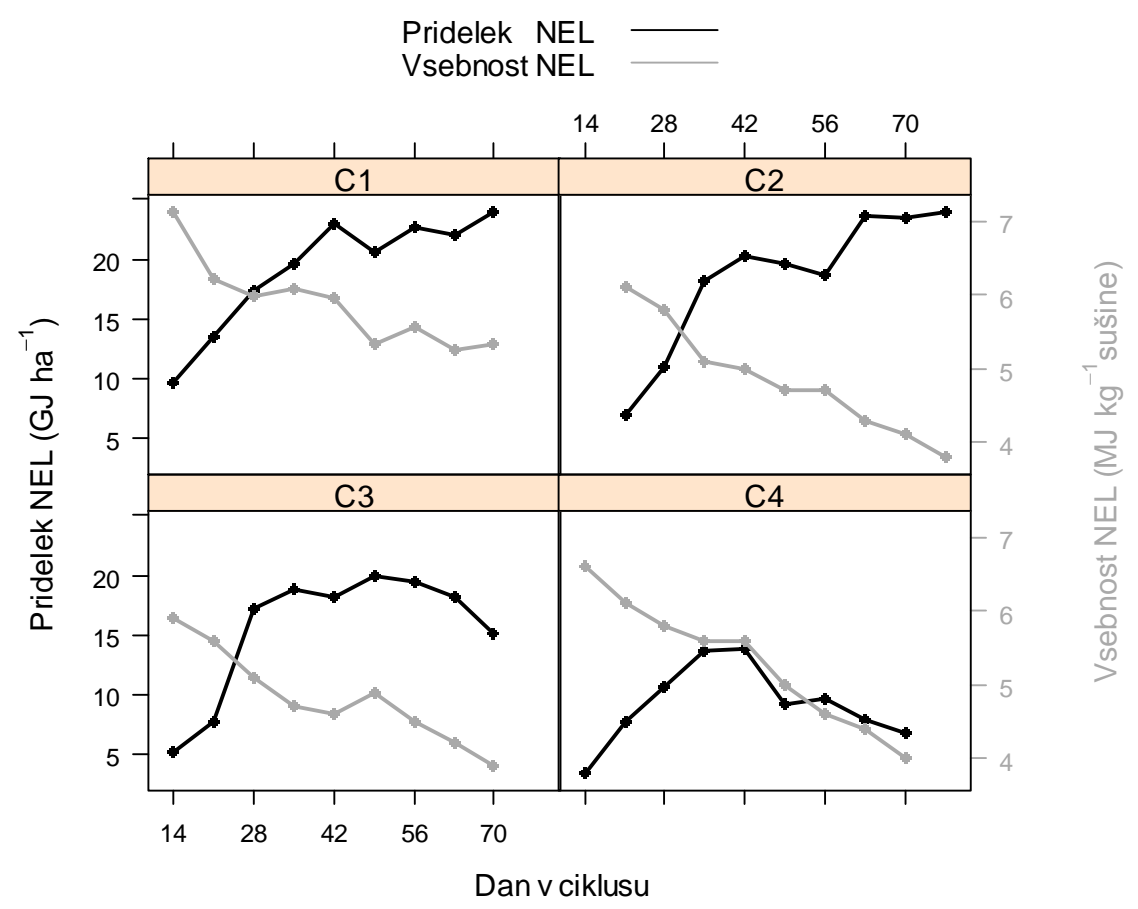

Slika 4: Časovni potek pridelka in vsebnosti NEL v zelinju lucerne po ciklusih (C1-C4) v rastni sezoni $2016 \mathrm{v}$ predalpskem podnebju Slovenije. Posamezne točke so povprečja dveh meritev.

Figure 4: Time pattern of yield and content of NEL in lucerne herbage during four growth cycles $(\mathrm{C} 1-\mathrm{C} 4)$ in the preAlpine climate of Slovenia in the season 2016. Data points are averages of two independent measurements. 


\section{RAZPRAVA}

\section{1 Časovni potek pridelka}

Časovni potek povečevanja pridelka zelinja smo modelirali z metodo lokalne regresije, ker se je izkazala za zadostno pri primerjavi le-teh med ciklusi. Izračunani gladilniki tudi kažejo obliko poteka pridelka zelinja in prelomna mesta. Po podobnosti potekov lahko cikluse razdelimo na spomladanski in zgodnje poletni par (C1 in C2) ter na poletni do jesenski par (C3 in C4). Prva dva ciklusa imata bolj linearni potek pridelka. Lucerna naj bi $\mathrm{v}$ teh dveh ciklusih tudi dosegla večja končna pridelka zelinja kot $\mathrm{v}$ drugih dveh zaradi ugodnejših, sezonsko povezanih, vremenskih razmer. To se je zgodilo $\mathrm{v}$ drugem ciklusu, ne pa $\mathrm{v}$ prvem, kjer je bila rast lucerne $\mathrm{v}$ drugi polovici ciklusa zelo ovirana zaradi poleglosti lucerne, ki so jo povzročile snežne padavine 27. aprila. Snežna odeja, debeline približno $15 \mathrm{~cm}$, je obstala na poskusu dva dni. Ker se polegla lucerna potem ni več dvignila, je to zmanjšalo njeno rast in povečalo razlike med ponovitvama. Bolj ugodne razmere za rast lucerne $\mathrm{v}$ prvi polovici sezone so $\mathrm{v}$ osrednji Sloveniji zato, ker v tem času ni izrazitih suš in ker so temperature zraka podobne optimalnim (24 do 25 ${ }^{\circ} \mathrm{C}$ podnevi in 18 do $19{ }^{\circ} \mathrm{C}$ ponoči; Stock, 1971). Pri drugih dveh ciklusih je potek pridelka podoben krivulji kvadratne funkcije. Priraščanje lucerne se je hitro začelo zmanjševati, $v$ prvem primeru predvsem zaradi suše, $v$ drugem pa zaradi suše in bližanja koncu rastne sezone. Negativni vpliv suše se je odrazil na masi in velikosti stebel, kar je dobro poznano (Fick in sod., 1988). Zasenčenost sestoja lucerne povzroči staranje in odpadanje listov na spodnjih delih poganjkov (Albrecht, 1983; Fick in sod., 1988). Pri lucerni v našem poskusu se je to odpadanje $\mathrm{v}$ večji meri začelo po 42. dnevu rasti. Obenem se je odmiranje in odpadanje listov povečalo v C4 zaradi okuženosti z lucernino rjo. Ker je bila rast proti koncu $\mathrm{C} 3$ in $\mathrm{C} 4$ manjša od mase odpadlih listov, se je pridelek zmanjševal. Vsi poteki povečevanja pridelka izkazujejo prelomno območje med 35. in 42. dnevom - prva dva ciklusa manj kot druga dva - po katerem se je rast lucerne zmanjšala. $V$ tem času je lucerna začela cveteti, razen v C1, ko je cvetenje nastopilo šele proti koncu ciklusa. Hitrejša rast lucerne pred cvetenjem kot po njem je dobro poznana in se odraža tudi v največjem letnem pridelku pri košnji, ko ima od 10 do $50 \%$ poganjkov cvetove (Albrecht, 1983). Primerjava časovnih potekov povečevanja pridelka zelinja $\mathrm{v}$ tej raziskavi $\mathrm{z}$ drugimi je težavna zaradi metodoloških razlik pri izvajanju poskusov in številu vključenih ciklusov. Vendar lahko ugotovimo, da je večina teh potekov iz drugih raziskav imelo tudi linearne ali $\mathrm{v}$ vrhnjem delu ukrivljene krivulje (npr. Kühbauch in Voigtländer, 1981; McGraw in Marten, 1986; Brink in sod., 2010).

\subsection{Modelirani časovni poteki PRF ter vsebnosti SB, NDV in NEL}

Morfološki razvoj lucerne, določen kot PRF, je bil najhitrejši v poletnih mesecih, to je v C2 in $\mathrm{C} 3$, kar je bila predvsem posledica višjih temperatur $\mathrm{v}$ tem času kot spomladi ali jeseni. Manj na to vpliva tudi večja dolžina dnevnega sončnega sevanja (fotoperioda). Navedena vpliva sta bila dokazana $\mathrm{v}$ več raziskavah (npr. Kalu in Fick, 1981). Najpočasneje se je lucerna razvijala v spomladanskem času, kar se je v veliki meri pozitivno odrazilo tudi na kakovosti krme. Morfološki razvoj je namreč zelo pomemben dejavnik kakovosti, čeprav ni edini, kot so dokazali Marvin in sod. (2000). Kultivarji lucerne, ki so izkazovali večjo kakovost krme med rastjo, se namreč niso razlikovali po razvojni fazi od tistih $\mathrm{z}$ manjšo kakovostjo. Linearna oblika časovnega poteka PRF, ugotovljena $\mathrm{v}$ tej raziskavi, se sklada z nekaterimi drugimi (Ohlsson, 1991; Božičković in sod., 2013) oziroma od njih odstopa (Kalu in Fick, 1981; Ohlsson, 1991). V teh zadnjih primerih so poteki podobni krivuljam kvadratne funkcije.

Kljub ugotovljenim razlikam $\mathrm{v}$ potekih vsebnosti SB med ciklusi so si ti $\mathrm{z}$ dvema izjemama na splošno podobni. Prvič, zmanjševanje vsebnosti SB v zadnjem delu $\mathrm{C} 1$ se je praktično ustavilo, kar je bilo povezano tako s počasnejšim morfološkim razvojem kot z nižjimi temperaturami zraka $\mathrm{v}$ maju. Verjetno so slednje povečale razmerje med listi in stebli in tudi upočasnile razvoj, kar je $\mathrm{v}$ skladu $\mathrm{z}$ navedbami Ficka in sod. (1988). Oboje se je potem poznalo na vsebnosti SB. Drugič, vsebnost $\mathrm{SB}$ je bila na začetku $\mathrm{C} 4$ zelo velika (291 $\mathrm{g} \mathrm{kg}^{-1}$ sušine), na koncu pa najmanjša (119 $\mathrm{g} \mathrm{kg}^{-1}$ sušine). Prvo bi lahko povezali s sušo v tem času, saj ta povečuje razmerje med listi in stebli $\mathrm{s}$ tem, da bolj zavira rast slednjih (Fick in sod. 1988). Drugo bi lahko povezali s povečanim odpadanjem zasenčenih in $\mathrm{z}$ rjo okuženih listov. Ta negativni vpliv na kakovost je bil očitno močnejši od nasprotnega vpliva suše, ki je trajala do konca tega ciklusa.

V obdobju do 56. dne, ki je lahko še pomembno za pridelovanje krme, so bile vse vsebnosti SB nad $150 \mathrm{~g}$ $\mathrm{kg}^{-1}$ sušine. Podobno velike vsebnosti $\mathrm{SB} v$ zelinju ostarele lucerne so ugotovili McGraw in Marten (1986) ter Hall in sod. (2000). V teh dveh virih je tudi oblika časovnega poteka vsebnosti SB enaka naši.

Časovni poteki vsebnosti NDV in NEL v lucerni med rastno sezono imajo nekaj skupnih značilnosti, kar kaže na precejšnjo povezanost teh dveh kazalcev kakovosti. Lucerna je bila po obeh kazalcih izrazito boljše kakovosti $\mathrm{v}$ C1 kot $\mathrm{v}$ drugih. To pomeni prehransko ugodnejšo najmanjšo vsebnost NDV in največjo 
vsebnost NEL skozi cel prvi ciklus. S kakovostjo lucerne se je $\mathrm{C} 1$ približal $\mathrm{C} 4$, a samo na začetku rasti. Razlogi za navedene razlike $\mathrm{v}$ potekih vsebnosti NDV in NEL so enaki kot pri SB: prvič, večja olistanost in počasnejši razvoj lucerne zaradi nižjih temperatur spomladi, drugič, večja olistanost mlade lucerne zaradi sušnih razmer $\mathrm{v}$ drugi polovici poletja in tretjič, povečano odpadanje listov lucerne zaradi zasenčevanja in okuženosti z rjo proti koncu rastne sezone.

Časovni poteki NDV v literaturi so, enako kot poteki v tej raziskavi, linearni oziroma so rahlo ukrivljeni (Kühbauch in Pletl, 1981; Ohlsson, 1991; Hall in sod., 2000). Sulc in sod. (1999) navajajo $400 \mathrm{~g} \mathrm{NDV} \mathrm{kg}^{-1}$ sušine kot optimalno vsebnost v lucerni. Temu kriteriju je $\mathrm{v}$ našem poskusu lucerna ustrezala do približno 45 . dne rasti $\mathrm{v}$ spomladanskem in pozno poletnem času, $\mathrm{v}$ osrednjem delu rastne sezone pa le do 30. dne. Objav o primerjavi rastnih ciklusov glede na potek NDV nismo našli. Prav tako nismo našli nobene objave o primerjavi rastnih ciklusov v poteku vsebnosti NEL. Žnidaršič in sod. (2015) so poročali le o zmanjševanju vsebnosti NEL med prvim ciklusom. Spremembe so bile hitrejše $\left(-0,041\right.$ MJ NEL $\mathrm{kg}^{-1}$ sušine na dan) kot $\mathrm{v} \mathrm{C} 1$ tega poskusa (-0,028 MJ NEL $\mathrm{kg}^{-1}$ sušine na dan), a podobne z vrednostmi za C2 in C4 (-0,039 MJ in -0,043 MJ NEL $\mathrm{kg}^{-1}$ sušine na dan; Preglednica 1).

Krave molznice morajo dobiti $\mathrm{v}$ določenih fazah laktacije obroke $\mathrm{z}$ večjo vsebnostjo energije, kot jo vsebuje najkakovostnejša voluminozna krma ( $>7 \mathrm{MJ}$ NEL $\mathrm{kg}^{-1}$ sušine). Pri oblikovanju priporočil za optimalen čas košnje upoštevamo načelo, da naj bo le ta opravljena $\mathrm{v}$ času, ko dovolj velik pridelek krme omogoča gospodarno spravilo. Za sejane trave velja, da jih je smiselno kositi najkasneje pri pridelku 3,5 t sušine $\mathrm{ha}^{-1}$, ko je pridelek že dovolj velik, energijska vrednost pa tudi še sprejemljiva (Van Middelaar in sod., 2014). V tem poskusu je bil pri prvih treh ciklusih omenjeni pridelek dosežen med 28. in 35. dnem po začetku rasti. $\mathrm{V}$ tej fazi rasti je lucerna $\mathrm{C} 1$ dosegla približno $6,0 \mathrm{MJ}$ NEL, lucerna C2 in C3 pa približno 5,0 MJ NEL $\mathrm{kg}^{-1}$ sušine. V C4 priporočen pridelek ni bil dosežen. Pokositi bi jo bilo smiselno med 35. in 42. dnem po začetku rasti, ko je že dosegla največji pridelek (približno 2,5 $\mathrm{t}_{\text {sušine }} \mathrm{ha}^{-1}$ ), vsebnost NEL pa je bila približno 5,6 $\mathrm{MJ} \mathrm{kg}^{-1}$ sušine. Rezultati kažejo, da $\mathrm{z}$ lucerno ni mogoče pridelati krme, ki bi zadostila kakovostnemu kriteriju za vsebnost energije $\mathrm{v}$ odlični travniški krmi $\left(>6,1 \mathrm{MJ}\right.$ NEL kg${ }^{-1}$ sušine; Verbič in sod., 2011). Ta kriterij je sicer bil dosežen ali presežen pri mladi lucerni v prvih 14. ali 21. dneh rasti $(\mathrm{C} 1, \mathrm{C} 4)$, vendar je takrat pridelek premajhen za košnjo. $\mathrm{Ob}$ tem je treba upoštevati, da molznice slabo energijsko vrednost lucerninega sena ali silaže deloma ali v celoti kompenzirajo s približno $10 \%$ večjo količino zaužite krme in ob tem dajo enako količino mleka kot z zelo kakovostno travniško krmo (Hoffman in sod., 1998; Bulang in sod., 2006).

\subsection{Primerjava časovnih potekov pridelkov in vsebnosti SB in NEL}

Dobra kazalnika uspešnosti pridelovanja voluminozne krme sta pridelka SB in NEL, ki morata biti dosežena ob sprejemljivi vsebnosti NEL. Ob zgoraj predlaganih časih košnje (med 28. in 35. dnem po začetku rasti pri $\mathrm{C} 1, \mathrm{C} 2$ in $\mathrm{C} 3$ in med 35 . in 42 . dnem po predhodni košnji pri $\mathrm{C} 4$ ), so se pri prvih treh ciklusih pridelki NEL gibali med približno $17 \mathrm{GJ}$ in $20 \mathrm{GJ}^{-1}$, pridelki SB pa med $600 \mathrm{~kg}$ in $700 \mathrm{~kg} \mathrm{ha}^{-1}$. Pri C4 sta bila pridelka manjša (približno $14 \mathrm{GJ} \mathrm{NEL} \mathrm{ha}{ }^{-1}$ in $500 \mathrm{~kg} \mathrm{SB} \mathrm{ha}^{-1}$ ). Zaradi razlik v dinamiki rasti (Slika 1 ) je bil $\mathrm{v}$ tem času pri C3 in C4 potencial za pridelek NEL že dosežen, pri $\mathrm{C} 1$ in $\mathrm{C} 2$ pa je bilo doseženo približno $80 \%$ največjega potenciala (Slika 4). Priraščanje pridelka SB se je ob predlaganih časih košnje pri vseh ciklusih $\mathrm{v}$ glavnem že zaključilo (Slika 3).

\section{ZAKLJUČKI}

Rast lucerne je bila v prvi polovici rastne sezone boljša kot $\mathrm{v}$ drugi, kar je posledica sezonsko pogojenih ugodnejših vremenskih razmer $\mathrm{v}$ tem času in običajno manjših okužb z glivami. Pridelek zelinja je $\mathrm{v}$ zadnjih dveh ciklusih hitro dosegel vrh in se nato začel zmanjšsevati zaradi povečanega odpadanja listov.

Morfološki razvoj lucerne je bil najhitrejši v poletnem času, med $\mathrm{C} 2$ in $\mathrm{C} 3$. Vendar je med vsemi ciklusi prvi izrazito odstopal s počasnim razvojem, kar je pozitivno vplivalo na kakovost krme.

Kakovost zelinja lucerne, vrednotena $\mathrm{z}$ vsebnostmi SB, NDV in NEL, je bila $v$ celoti najboljša med $\mathrm{C} 1$. To bolj velja za NDV in NEL kot SB. Lucerna v C4 je bila na začetku enako kakovostna kot $\mathrm{v} \mathrm{C} 1$, a se je nato njena kakovost hitreje zmanjševala.

Rezultati raziskave so pokazali, da je optimalna starost lucerne ob košnji, glede na pridelek in vsebnost NEL, od 28 do 35 dni spomladi in poleti ter od 35 do 42 dni jeseni. Ob takšnem času rabe vsebuje lucerna $\mathrm{C} 1$ približno 6,0 MJ NEL, lucerna $\mathrm{C} 2$ in $\mathrm{C} 3$ približno 5,0 MJ NEL, lucerna C4 pa približno 5,6 MJ NEL $\mathrm{kg}^{-1}$ sušine.

Raziskava je bila opravljena $\mathrm{v}$ okviru Ciljnega raziskovalnega programa »Zagotovimo.si hrano za 
jutri«, projekt Tehnološke rešitve za boljše izkoriščanje lucerne v prehrani prežvekovalcev (V4-1414). Projekt sta sofinancirala Ministrstvo za kmetijstvo, gozdarstvo in prehrano ter Javna agencija za raziskovalno dejavnost Republike Slovenije iz državnega proračuna.

\section{VIRI}

Albrecht, K. A. (1983). Studies on nitrogen accumulation, fiber chemistry, and in vitro digestibility of alfalfa. Retrospective Theses and Dissertations. 8448. URL http://lib.dr.iastate.edu/rtd/8448

Blümmel, M., \& Ørskov, E. R. (1993). Comparison of in vitro gas production and nylon bag degradability of roughages in predicting feed intake in cattle. Animal Feed Science and Technology, 40, 109-119. doi:10.1016/0377-8401(93)90150-I

Bowley, S. R., Dougherty, C. T., Taylors, N. L., \& Cornelius, P. L. (1988). Comparison of yield components of red clover and alfalfa. Canadian Journal of Plant Science, 68, 103-114. doi:10.4141/cjps88-011

Božičković, A., Grubić, G., Verbič, J., Žnidaršič, T., Djordjević, N., \& Stojanović, B. (2013). A modified method for assessment of the morphological stage of development as a predictor of alfalfa herbage chemical composition and nutritive value. Journal of Agricultural Science, 151, 590-598. doi:10.1017/S0021859613000129

Brink, G., Hall, M., Shewmaker, G., Undersander, D., Martin, N., \& Walgenbach, R. (2010). Changes in alfalfa yield and nutritive value within individual harvest periods. Agronomy Journal, 102, 12741282. doi:10.2134/agronj2010.0080

Brown, H. E., Moot, D. J., \& Pollock, K. M. (2005). Herbage production, persistence, nutritive characteristics and water use of perennial forages grown over 6 years on a Wakanui silt loam. New Zealand Journal of Agricultural Research, 48, 423439. doi:10.1080/00288233.2005.9513677

Bulang, M., Kluth, H., Engelhard, T., Spike, J., \& Rodehutscord, M. (2006). Zum Einzatz von Luzernesilage bei Kühen mit hoher Milchleistung. Journal of Animal Physiology and Animal Nutrition, 90, 89-102. doi:10.1111/j.14390396.2005.00568.x

Fick, G. W., Holt, D. A., \& Lugg, D. G. (1988). Environmental physiology and crop growth. In A. A. Hanson, D. K. Barnes \& Hill R. R. (Eds.), Alfalfa and alfalfa improvement (pp. 163-194). Madison, Wisconsin, USA: ASA, CSSA, SSSA.

GfE [Gesellschaft für Ernährungsphysiologie]. (2016). Equations for predicting metabolisable energy and digestibility of organic matter in forage legumes for ruminants. Communications of the Committee for Requirement Standards of the Society of Nutrition Physiology. URL http://www.gfefrankfurt.de/download/Equations_in_forage_legum es_ruminants.pdf

Hall, M. H., Scott Smiles, W., \& Dickerson, A. (2000). Morphological development of alfalfa cultivars selected for higher quality. Agronomy Journal, 92, 1077-1080. doi:10.2134/agronj2000.9261077x

Hoffman, P. C., Combs, D. K., \& Casler, M. D. (1998). Performance of lactating dairy cows fed alfalfa silage or perennial ryegrass silage. Journal of Dairy Science, 81, 162-168. doi:10.3168/jds.S00220302(98)75563-8

International organisation for standardisation. (2000). Animal feeding stuffs. Determination of crude fibre content - Method with intermediate filtration (ISO Standard 6865).

International organisation for standardisation. (2002). Animal feeding stuffs. Determination of crude ash (ISO Standard 5984).

International organisation for standardisation. (2005). Animal feeding stuffs. Determination of nitrogen content and calculation of crude protein content. Part 1: Block digestion/steam distillation method (ISO Standard 5983-2).

Kalu, A. B., \& Fick, W. G. (1981). Quantifying morphological development of alfalfa for studies of herbage quality. Crop Science, 21, 267-271. doi:10.2135/cropsci1981.0011183X002100020016 $\mathrm{X}$

Kalu, B. A., \& Fick, G. W. (1983). Morphological stage of development as a predictor of alfalfa herbage quality. Crop Science, 23, 1167-1172. doi:10.2135/cropsci1983.0011183X002300060033 $\mathrm{X}$

Kühbauch, W., \& Pletl, L. (1981). Berechnung der Futterqualität bei Weißklee, Rotklee und Luzerne nach morphologischen Kriterien und/oder aus Pflanzeninhaltsstoffen. II. Mitteilung: Berechnung der Stengel- und Blätterverdaulichkeit bei Rotklee und Luzerne aus Komponenten von Zellwand und Zellinhalt. Zeitschrift für Acker- und Pflanzenbau, 150, 281-290. 
Kühbauch, W., \& Voigtländer, G. (1981). Berechnung der Futterqualität bei Weißklee, Rotklee und Luzerne mit morphologischen Kriterien und/oder aus Pflanzeninhaltsstoffen. III. Mitteilung: Ertragsbildung und Futterqualtät bei Rotklee und Luzerne unter besonderer berücksichtigung der morphologischen Differenzierung. Zeitschrift für Acker- und Pflanzenbau, 150, 339-348.

Lloveras, J., Chocarro, C., Torres, L., Viladrich, D., Costafreda, R., \& Santiveri, F. (2012). Alfalfa yield components and soil potassium depletion as affected by potassium fertilization. Agronomy Journal, 104, 729-734. doi:10.2134/agronj2011.0293

Marten, G. C., Buxton, D. R., \& Barnes R. F. (1988). Feeding value (Forage quality). In: A. A. Hanson, D. K. Barnes \& Hill R. R. (Eds.), Alfalfa and alfalfa improvement (pp. 463-491). Madison, Wisconsin, USA: ASA, CSSA, SSSA.

McGraw, R. L., \& Marten, G. C. (1986). Analysis of primary spring growth of four pasture legume species. Agronomy Journal, 78, 704-710. doi:10.2134/agronj1986.00021962007800040029x

Menke, K. H., Raab, L., Salewski, A., Steingass, H., Fritz, D., \& Schneider, W. (1979). The estimation of the digestibility and metabolizable energy content of ruminant feedingstuffs from the gas production when they were incubated with rumen liquor in vitro. Journal of Agricultural Science, 93, 217-222. doi:10.1017/S0021859600086305

Ohlsson, C. (1991). Growth, development, and composition of temperate forage legumes and grasses in varying environments. Retrospective Theses and Dissertations. 9563. URL http://lib.dr.iastate.edu/rtd/9563

R Core Team (2016). R: A language and environment for statistical computing. $R$ Foundation for Statistical Computing, Vienna, Austria. URL https://www.R-project.org/.

Rizk, C. (2004). Effects of inoculation on alfalfa silage quality and its feeding on the performance of dairy cattle. Master of Science Thesis (98 p.), Montreal, Quebec: McGill University.

Roberts, C. A., Stuth, J., \& Finn, P. C. (2004). NIRS applications in forages and feedstuffs. In: C. A. Roberts, J. Workman \& Reeves J. B. (Eds.), NearInfrared Spectroscopy in Agriculture (pp. 231-268). Agronomy Monograph 44. Madison, Wisconsin, ASA, CSSA, SSSA.
Russelle, M. P. (2001). Alfalfa: After an 8,000-year journey, the "Queen of Forages" stands poised to enjoy renewed popularity. American Scientist, 89, 252-261. doi:10.1511/2001.3.252

Stock, H. G. (1971). Die Wirkung von Temperatur, Bodenfeuchte und Windgeschwindigkeit auf das Wachstum von Rotklee und Luzerne. Archiv für Acker- und Pflanzenbau und Bodenkunde, 15, 951962.

Sulc, R. M., Albrecht, K. A., Owens, V. N., \& Cherney, J. H. (1999). Update on predicting harvest time for alfalfa. In M. L. Eastridge (Ed.), Proceedings TriState Dairy Nutrition Conference (pp. 167-177). Fort Wayne, Indiana: The Ohio State University.

Uredba Komisije (ES) 152/2009. (2009). Uredba Komisije (ES) št. 152/2009 z dne 27. januarja 2009 o določitvi metod vzorčenja in analitskih metod za uradni nadzor krme. URL http://eurlex.europa.eu/LexUriServ/LexUriServ.do?uri=OJ:L :2009:054:0001:0130:SL:PDF

Van Middelaar, C. E., Dijkstra, J., Berentsen, P. B. M., \& De Boer, I. J. M. (2014). Cost-effectiveness of feeding strategies to reduce greenhouse gas emissions from dairy farming. Journal of Dairy Science, 97, 2427-2439. doi:10.3168/jds.20137648

Van Soest, P. J., Robertson, J. B., \& Lewis, B. A. (1991). Methods for dietary fiber and nonstarch polysaccharides in relation to animal nutrition. Journal of Dairy Science, 74, 3583-3597. doi:10.3168/jds.S0022-0302(91)78551-2

Verbič, J., Čeh, T., Gradišer, T., Janžekovič, S., Lavrenčič, A., Levart, A., Perpar, T., Velikonja Bolta, Š., \& Žnidaršič, T. (2011) Kakovost voluminozne krme in prireja mleka v Sloveniji. V: T. Čeh (ur.), S. Kapun (ur.), Zbornik predavanj 20. mednarodno znanstveno posvetovanje o prehrani domačih živali "Zadravčevi-Erjavčevi dnevi" (str. 97-110). Murska Sobota, Kmetijsko gozdarska zbornica Slovenije, Kmetijsko gozdarski zavod.

Verbič, J., \& Verbič, J. (2017). Lastnosti lucerne za siliranje. Naše travinje, 11, 18-19.

Whitehead, D. C. (1972). Chemical composition. In C. R. W. Spedding \& E. C. Diekmahns (Eds.), Grasses and legumes in British agriculture (pp. 326-342). Farnham Royal, Bucks, England: CAB.

Žnidaršič, T., Verbič, J., Verbič, J., \& Kopač, P. (2015). Kemična sestava in energijska vrednost posameznih vrst trav in metuljnic prve košnje v povezavi s časom košnje. Naše travinje, 9, 17-20. 